\title{
Investigation of Some Possible Mechanisms Involved in the Anticonvulsant Activity of Tulbaghia violacea Harv
}

\author{
K. A. A. Masoud ${ }^{1}$, Okobi E Ekpo ${ }^{1}$ and G. J. Amabeoku ${ }^{2}$ \\ 1. Department of Medical Biosciences, University of the Western Cape, Bellville 7535, South Africa \\ 2. School of Pharmacy, Faculty of Natural Science, University of the Western Cape, Bellville 7535, South Africa
}

\begin{abstract}
Even though Tulbaghia violacea has been used to treat and manage epilepsy in South Africa by traditional medicine practitioners, no evidence in any literature has shown any scientific scrutiny of the effectiveness of the plant species in therapy. This study was intended, therefore, to investigate the anticonvulsant effect of the leaf methanol extract of Tulbaghia violacea by studying its effect against tonic convulsion induced by either PTZ (pentylenetetrazole), bicuculline, picrotoxin, strychnine or NMDLA (N-methyl-DL-aspartic acid) in mice. Qualitative phytochemical analysis, acute toxicity and HPLC studies were also carried out on the plant species. Leaf methanol extract of Tulbaghia violacea, phenobarbitone, diazepam or muscimol significantly antagonised PTZ, bicuculline or picrotoxin-induced convulsion. Combined treatment of sub-effective doses of $T$. violacea and muscimol significantly antagonised tonic convulsion induced by PTZ. T. violacea or phenobarbitone significantly antagonised strychnine-induced tonic convulsion. T. violacea or LY233053 significantly antagonised NMDLA-elicited tonic convulsion. Phenytoin or DMSO (dimethylsulfoxide) did not significantly affect the tonic convulsion produced by PTZ, bicuculline, picrotoxin, strychnine or NMDLA. The phytochemical qualitative analysis of the plant species showed the presence of alkaloids, saponins, reducing sugars, flavonoids, cardiac glycosides, triterpene steroids, quinones and tannins. The LD50 value obtained following oral administration of the plant extract was over $4000 \mathrm{mg} / \mathrm{kg}$. The data in the present study indicate that the leaf methanol extract of T. violacea has anticonvulsant activity which is probably underpinned by GABAergic, glutaminergic and glycinergic mechanisms.
\end{abstract}

Key words: Tulbaghia violacea, alliaceae, anticonvulsant properties, GABAergic, glutamatergic and glycinergic mechanisms, mice.

\section{Introduction}

Epilepsy is a chronic neurological disorder characterized by spontaneous recurrent seizures [1]. It is one of the most common neurological disorders affecting approximately 50 million people worldwide $[2,3]$, mainly in developing countries $[4,5]$. People with epilepsy usually conceal their condition due to the fear of stigmatization and discrimination [6]. There is as yet no known cure for epilepsy but it can be controlled [7]. It is known that approximately one third of the people with epilepsy have drug-resistant seizures [8] and less than $50 \%$ of affected people in developing countries receive medication [9]. Even newer AEDs (antiepileptic drugs) have been reported to have significant CNS side-effects including decreased

Corresponding author: George Jimboyeka Amabeoku, Ph.D., professor, research fields: pharmacology and ethnopharmacology. cognitive abilities and psychiatric complications [10].

In some Asian and African countries, up to $80 \%$ of the population relies on traditional (folk) medicine for their primary health care needs [11], possibly due to the high cost of conventional medicines. In South Africa, approximately, three million people in both urban and rural areas are reported to be reliant on traditional medicine exclusively or in combination with western medicine [12-16]. One South African study found that some people with epilepsy combined western and traditional medicines viz-a-viz plant medicines for the treatment of epilepsy [17]. Although natural products are widely used by people with epilepsy all over the world, there is currently little evidence about their safety and efficacy to scientifically justify their use. Raskin [18] acknowledged that plant-derived compounds are excellent sources for novel pharmaceutical products. According to Ekstein and 
Schachter [19], natural products with a long history of medicinal use in epilepsy or relevant mechanisms of action should be further tested using systematic pre-clinical methods and rigorously studied in people with epilepsy where appropriate, as potential new treatments for epilepsy.

Tulbaghia violacea Harv belongs to the family of Alliaceae. It grows up to a height $0.2-0.45 \mathrm{~m}$. It is a medicinal herb widely used in some communities in South Africa to treat various ailments including fever, tuberculosis, asthma, stomach problems, oesophageal cancer and epilepsy [12]. Even though Allium sativum, belonging to the same family as $T$. violacea, has been reported to have potent anticonvulsant activity [20], there is no evidence in any literature to scientifically corroborate the effectiveness of $T$. violacea in the treatment of epilepsy in South Africa. The core aim of this study, therefore, was to evaluate the anticonvulsant activity of $T$. violacea in mice.

\section{Materials and Methods}

\subsection{Plant Material}

Fresh leaves of Tulbaghia violacea were collected from Kirstenbosch National Botanical Garden, South Africa, in March 2014, at an altitude of 3-1220 m. The identity of the leaves was confirmed by the curator of the Garden and also by a taxonomist, Mr F. Weitz, in the Department of Biodiversity and Conservation Biology, University of the Western Cape. A voucher specimen of T. volacea (Amabeoku 007) was then deposited in the Herbarium at the University of the Western Cape, South Africa.

\subsection{Preparation of the Leaf Methanol Extract of T. violacea}

The fresh leaves of the plant species were separated from the branches of the plant, weighed $(1.7 \mathrm{~kg})$ and then washed with distilled water. They were dried in a ventilated oven at $35{ }^{\circ} \mathrm{C}$ for 4 days. The dried leaves $(818.1 \mathrm{~g})$ were ground into fine powder $(486 \mathrm{~g})$ using the Waring Commercial laboratory blender. To prepare the leaf methanol extract of $T$. violacea, sixty gram $(60 \mathrm{~g})$ of the dried powder was extracted in a Soxhlet extractor with $500 \mathrm{~mL}$ of methanol for $4 \mathrm{~h}$. The methanol filtrate obtained was evaporated to dryness using a Buchi RE11 rotavapor and Buchi 461 water bath and $5.83 \mathrm{~g}$ of crude methanol extract was obtained. This was then preserved in a desiccator for further studies. Fresh solution of the crude leaf methanol extract of $T$. violacea was prepared on each day of the experiment by dissolving a weighed quantity of the crude methanol extract in a minimum volume of DMSO (dimethylsulfoxide) and then, made up to the appropriate volume with physiological saline. The solution was injected intraperitoneally (i.p.) to mice in a volume of $1 \mathrm{~mL} / 100 \mathrm{~g}$ of body weight of animal.

\subsection{Animals}

Male and female albino mice were used for the study. These animals were bred in the animal house of the Discipline of Pharmacology and Clinical Pharmacy, School of Pharmacy, University of the Western Cape, South Africa. They weighed between $18 \mathrm{~g}$ and $30 \mathrm{~g}$ and were used in groups of eight for each dose of plant extract or drug. The animals had access to food and water ad libitum. All animals were fasted for $16 \mathrm{~h}$ during which they had access to water before the commencement of the experiments. Laboratory conditions of temperature $\left(22 \pm 1{ }^{\circ} \mathrm{C}\right)$, humidity and a $12 \mathrm{~h}$ light $/ 12 \mathrm{~h}$ dark cycle were maintained at all times during the experiments. Each animal was used only once in the experiments.

\subsection{Drugs and Chemicals}

Strychnine (Sigma Chemical Co), pentylenetetrazole (PTZ, Sigma Chemical Co.), picrotoxin (Sigma Chemical Co.), N-methyl-DL-aspartic acid (NMDLA, Sigma Chemical Co.), phenobarbitone sodium (BDH Chemicals Ltd), LY233053 (Sigma Chemical Co.), muscimol (Sigma Chemical Co.) and 5,5 diphenylhydantoin sodium salt (Phenytoin, Sigma Chemical Co.) were dissolved in physiological saline 
to the appropriate volumes. (+) Bicuculline (Sigma Chemical Co.) was suspended in a minimum amount of Tween 80 and adjusted to the appropriate volume with physiological saline. Diazepam (Valium, Roche, South Africa) was dissolved in a minimum amount of propylene glycol and made up to the appropriate volume with physiological saline. Dimethylsulfoxide (DMSO, Sigma Chemical Co.) solution was prepared by dissolving equal volume, used to dilute the plant extract, in an appropriate volume of physiological saline. All drugs were injected intraperitoneally (i.p.) in a volume of $1 \mathrm{~mL} / 100 \mathrm{~g}$ of body weight of animal. Equal volume injections of the appropriate vehicles such as physiological saline and DMSO were given to the control animals. Fresh solutions of the plant extract or drugs were prepared on each day of the experiment. The doses of the leaf methanol extract of $T$. violacea used were obtained from preliminary studies in our laboratory. The pre-treatment times of the plant extract and the standard antiepileptic drugs used were obtained from previous studies [21]. The pre-treatment times following the administration of pentylenetetrazole, bicuculline, picrotoxin, strychnine or NMDLA were 15 min (plant extract), $10 \mathrm{~min}$ (phenobarbitone), $20 \mathrm{~min}$ (diazepam), $20 \mathrm{~min}$ (phenytoin), $30 \mathrm{~min}$ (LY233053), 1 $\mathrm{h}$ (muscimol) and $15 \mathrm{~min}$ (DMSO solution).

\subsection{Phytochemical Analysis of Tulbaghia violacea}

Phytochemical analysis was performed on the dried powdered leaf of the plant species using the methods of Harbone [22] and Ikhiri et al. [23] to screen for chemical compounds including alkaloids, saponins, reducing sugars, flavonoids, cardiac glycosides, triterpene steroids, quinones and tannins.

\subsection{High Performance Liquid Chromatographic (HPLC) Analysis}

Chromatographic system: Agilent 1200 system consisting of degassing system, quaternary pump, auto loading sampler, thermostatted column compartment, diode array detector, fluorescence detector, analyte fraction collector and Agilent Chem Station software; column: Phenomenex Luna (C18) $5 \mu \mathrm{m}$ and dimensions $(250 \mathrm{~cm} \times 4.6 \mathrm{~mm})$.

Chromatographic conditions: Mobile phase degassed with helium, solvent $\mathrm{A}$ : water containing $0.1 \%$ formic acid; solvent B: Acetonitrile containing 0.1\% formic acid, Mode: flow rate, $0.8 \mathrm{~mL} / \mathrm{min}$; injection volume, $50 \mu \mathrm{L}$, detector, $\mathrm{UV}$ at $370 \mathrm{~nm}$. The eluent was monitored at several wavelengths ranging from 210 to $370 \mathrm{~nm}$, the specific wavelength of interest being 350 $\mathrm{nm}$. The HPLC operating conditions were programmed to give the following: $0 \mathrm{~min}$, solvent $\mathrm{B}: 18 \% ; 15 \mathrm{~min}$, solvent B: $25 \%$; 20 min, solvent B: 35\%, 30 min, solvent B: $90 \%$. The run rate was $30 \mathrm{~min}$.

\subsection{Anticonvulsant Activity Assessment}

The method of Vellucci and Webster [24] as modified by Amabeoku and Kinyua [21], was used to evaluate the anticonvulsant activity of the leaf methanol extract of Tulbaghia violacea. The mice were acclimatized to their new environment by housing them singly in transparent perspex mice cages $30 \mathrm{~min}$ before the commencement of the experiments. Eight control animals were pretreated for 15 min with physiological saline $(0.25 \mathrm{~mL}$, i.p. $)$ and then followed by pentylenetetrazole (PTZ, $100 \mathrm{mg} / \mathrm{kg}$, i.p.), bicuculline (40 mg/kg, i.p.), picrotoxin (20 mg/kg, i.p.), strychnine $(2 \mathrm{mg} / \mathrm{kg}$, i.p. $)$ and N- methyl-DL-aspartic acid (NMDLA, $400 \mathrm{mg} / \mathrm{kg}$, i.p.), all of which are standard convulsant drugs, administered separately to the mice to produce convulsion. The animals were observed for $30 \mathrm{~min}$ for tonic convulsion. Seizures were manifested as tonic hind-limb extensions. The time of the onset of tonic seizures and proportion of animals convulsing or not convulsing were obtained during the $30 \mathrm{~min}$ period of observation. Test animals, eight per group, were pre-treated with either the leaf methanol extract of $T$. violacea $(100-400 \mathrm{mg} / \mathrm{kg}$, i.p.), phenobarbitone (12 mg/kg, i.p.), diazepam $(0.5 \mathrm{mg} / \mathrm{kg}$, i.p.), phenytoin (30 $\mathrm{mg} / \mathrm{kg}$, i.p.), muscimol (0.2-2 $\mathrm{mg} / \mathrm{kg}$, i.p), LY233053 (5 mg/kg, i.p.) or DMSO (0.25 
$\mathrm{ml}$, i.p.) prior to the administration of any of the convulsant agents. The animals were also observed for $30 \mathrm{~min}$ for tonic convulsion. The time of the onset of seizures and proportion of animals convulsing or not convulsing were obtained during the $30 \mathrm{~min}$ period of observation. The experiment was repeated with another group of eight mice pretreated with combined sub effective doses of leaf methanol extract of $T$. violacea $(100 \mathrm{mg} / \mathrm{kg}$, i.p.) and muscimol $(0.2 \mathrm{mg} / \mathrm{kg}$, i.p. $)$ prior to the administration of PTZ $(100 \mathrm{mg} / \mathrm{kg}$, i.p.). The ability of the plant extract to prevent or delay the onset of the tonic hind limb extensions was taken as an indication of anticonvulsant activity [21, 25]. All the experiments were carried out in a quiet laboratory at an ambient temperature of $22 \pm 1{ }^{\circ} \mathrm{C}$ and between $09 \mathrm{~h} 00$ $-17 \mathrm{~h} 00$ on each day of the experiment.

\subsection{Acute Toxicity Study}

The methods described by Hilaly et al. [26] and Lorke [27] and modified by Ojewole [28] were used for the acute toxicity study of $T$. violacea. The acute toxicity study was carried out to determine the median lethal dose $\left(\mathrm{LD}_{50}\right)$ of the plant extract. Mice were fasted for $16 \mathrm{~h}$ and then randomly divided into groups of eight per cage. Graded doses of the plant extract $(100,200$, $400,800,1,200,1,600,2,000,2,400,2,800,3,200$, 3,600 and $4,000 \mathrm{mg} / \mathrm{kg}$ ) were separately administered orally by means of a bulbed steel needle to mice in each test group. The control group received $0.25 \mathrm{~mL}$ (p.o.) of physiological saline by means of a bulbed steel needle. The mice were then allowed free access to food and water and observed for 5 days for signs of acute toxicity including death. In the case of any death occurring at any dose range within the 5 days observation period, log dose-response curves would be constructed for the plant extract from which the median lethal dose would be calculated.

\subsection{Statistical Analysis}

The results on the onset of tonic convulsion were analyzed using one way analysis of variance (ANOVA) followed by Dunnett's multiple comparison test (GraphPad Prism, version 5.0, Graph Pad software, Inc., San Diego Cap2130, USA). The number of animals convulsing was analysed using the chisquared test [29]. The data obtained were expressed as mean \pm SEM (standard error mean). $p$ values of less than $5 \%(p<0.05)$ were considered statistically significant.

\subsection{Ethical Considerations}

The experimental protocol used in this study was approved (14/7/46) by the University of the Western Cape Ethics Committee, Bellville 7535, South Africa and conforms to the University's Regulations Act concerning animal experiments.

\section{Results}

\subsection{Phytochemical Analysis}

The phytochemical quantitative analysis of the dried powdered leaf of $T$. violacea showed that the plant species contains the following chemical components, alkaloids, saponins, reducing sugars, flavonoids, cardiac glycosides, triterpene steroids, quinones and tannins.

\subsection{Pharmacological Activity Assessment}

3.2.1 Effect of leaf methanol extract of TV (Tulbaghia violacea) on pentylenetetrazole (PTZ)-induced tonic convulsion

Pentylenetetrazole $(100 \mathrm{mg} / \mathrm{kg}$, i.p.) elicited tonic convulsion in all the eight mice administered with the convulsant agent. Leaf methanol extract of Tulbaghia violacea $(100 \mathrm{mg} / \mathrm{kg}$, i.p.) did not significantly affect the onset or incidence of PTZ $(100 \mathrm{mg} / \mathrm{kg}$, i.p.)-induced tonic convulsion. The doses of 200 $(\mathrm{mg} / \mathrm{kg}$, i.p.) and $400(\mathrm{mg} / \mathrm{kg}$, i.p.) of the leaf methanol extract of $T$. violacae significantly delayed the onset of PTZ $(100 \mathrm{mg} / \mathrm{kg}$, i.p.)-induced tonic convulsion in a dose dependent manner. Leaf methanol extract of the plant species (200 and $400 \mathrm{mg} / \mathrm{kg}$, i.p.) significantly delayed the onset but did not affect the incidence of 
PTZ (100 mg/kg, i.p.)-induced tonic convulsion. The dose of $400 \mathrm{mg} / \mathrm{kg}$ (i.p.) of the leaf methanol extract of T. violacea protected $12.5 \%$ of mice against the tonic convulsion. Phenobarbitone (12 mg/kg, i.p.), diazepam $(0.5 \mathrm{mg} / \mathrm{kg}$, i.p.) or muscimol $(2 \mathrm{mg} / \mathrm{kg}$, i.p.) significantly delayed the onset of PTZ $(100 \mathrm{mg} / \mathrm{kg}$, i.p.)-induced tonic convulsion and also significantly reduced the number of animals convulsing. Both phenobarbitone (12 $\mathrm{mg} / \mathrm{kg}$, i.p.) and diazepam protected $100 \%$ of mice against the tonic convulsion respectively. Muscimol (2 mg/kg, i.p.) protected $62.5 \%$ of mice against PTZ $(100 \mathrm{mg} / \mathrm{kg}$, i.p.)-induced tonic convulsion. Muscimol $(0.2 \mathrm{mg} / \mathrm{kg}$, i.p. $)$ did not significantly affect the onset or incidence of PTZ (100 $\mathrm{mg} / \mathrm{kg}$, i.p.)-induced tonic convulsion. However, combined therapy of sub effective doses of the leaf methanol extract of $T$. violacea $(100 \mathrm{mg} / \mathrm{kg}$, i.p.) and muscimol $(0.2 \mathrm{mg} / \mathrm{kg}$, i.p. $)$ significantly delayed the onset of PTZ $(100 \mathrm{mg} / \mathrm{kg}$, i.p.)-induced tonic convulsion and but did not significantly reduce the number of animals convulsing. The combined therapy of sub effective doses of the leaf methanol extract of $T$. violacea (100 mg/kg, i.p.) and muscimol $(0.2 \mathrm{mg} / \mathrm{kg}$, i.p.) protected $25 \%$ of mice against the tonic convulsion. Phenytoin (30 mg/kg, i.p.) or DMSO (0.25 $\mathrm{ml}$, i.p.) did not significantly affect the onset or incidence of PTZ (100 mg/kg, i.p.)-induced tonic convulsion (Table 1).

3.2.2 Effect of leaf methanol extract of TV (Tulbaghia violacea) on bicuculline-induced tonic convulsion

Bicuculline (30 $\mathrm{mg} / \mathrm{kg}$, i.p.) produced tonic convulsion in all the eight mice used for the experiment. Leaf methanol extract of Tulbaghia violacea $(100-400 \mathrm{mg} / \mathrm{kg}$, i.p.) significantly and dose dependently delayed the onset of tonic convulsion produced by bicuculline $(30 \mathrm{mg} / \mathrm{kg}$, i.p.) but did not affect the incidence of the convulsion. Phenobarbitone (12 $\mathrm{mg} / \mathrm{kg}$, i.p.), diazepam (0.5 $\mathrm{mg} / \mathrm{kg}$, i.p.) or muscimol $(2 \mathrm{mg} / \mathrm{kg}$, i.p. $)$ significantly delayed the onset of bicuculline $(30 \mathrm{mg} / \mathrm{kg}$, i.p.)-induced tonic convulsion and also significantly reduced the number of animals convulsing. Phenobarbitone $(12 \mathrm{mg} / \mathrm{kg}$, i.p.), diazepam $(0.5 \mathrm{mg} / \mathrm{kg}$, i.p.) or muscimol $(2 \mathrm{mg} / \mathrm{kg}$, i.p.) protected $87.5 \%$ of mice against bicuculline (30 $\mathrm{mg} / \mathrm{kg}$, i.p.)-induced tonic convulsion. Phenytoin (30 $\mathrm{mg} / \mathrm{kg}$, i.p.) or DMSO (0.25 mL, i.p.) did not significantly affect the onset or incidence of bicuculline (30 mg/kg, i.p.)-induced tonic convulsion (Table 2).

Table 1 Effect of leaf methanol extract of TV (Tulbaghia violacea) on PTZ (pentylenetetrazole)-induced tonic convulsion in mice.

\begin{tabular}{|c|c|c|c|c|c|c|c|c|c|c|}
\hline \multicolumn{2}{|c|}{ Dose $(\mathrm{mg} / \mathrm{kg})$} & \multirow[t]{2}{*}{ Phenobarbitone } & \multirow[t]{2}{*}{ Diazepam } & \multirow[t]{2}{*}{ Phenytoin } & \multirow[t]{2}{*}{ Muscimol } & \multirow[t]{2}{*}{ DMSO } & \multirow{2}{*}{$\begin{array}{l}\text { No convulsed/No } \\
\text { used }\end{array}$} & \multirow{2}{*}{$\begin{array}{l}\text { Percentage } \\
\text { protection } \\
(\%)\end{array}$} & \multicolumn{2}{|c|}{$\begin{array}{l}\text { Onset of tonic } \\
\text { convulsion (min) }\end{array}$} \\
\hline $\mathrm{PCN}$ & TV & & & & & & & & \multicolumn{2}{|c|}{ Mean \pm SEM } \\
\hline 100 & - & - & - & - & - & - & $8 / 8$ & & 2.50 & 0.33 \\
\hline 100 & 100 & - & - & - & - & - & $8 / 8$ & 0 & 9.0 & 2.89 \\
\hline 100 & 200 & - & - & - & - & - & $8 / 8$ & 0 & $13.68^{*}$ & 2.51 \\
\hline 100 & 400 & - & - & - & - & - & $7 / 8$ & 12.5 & $18.38^{*}$ & 1.99 \\
\hline 100 & - & 12 & - & - & - & - & $0 / 8^{++}$ & 100 & $0^{*}$ & \\
\hline 100 & - & - & 0.5 & - & - & - & $0 / 8^{++}$ & 100 & $0^{*}$ & \\
\hline 100 & - & - & - & 30 & - & - & $8 / 8$ & 0 & 2.41 & 0.66 \\
\hline 100 & - & - & - & - & 2 & - & $3 / 8^{+}$ & 62.5 & $21.0^{*}$ & 4.42 \\
\hline 100 & - & - & - & - & 0.2 & - & $8 / 8$ & 0 & 2.88 & 0.52 \\
\hline 100 & 100 & - & - & - & 0.2 & - & $6 / 8$ & 25 & $14.50^{*}$ & 4.11 \\
\hline 100 & - & - & - & - & - & $0.25 \mathrm{~mL}$ & $8 / 8$ & 0 & 2.75 & 0.37 \\
\hline
\end{tabular}


Table 2 Effect of leaf methanol extract of TV (Tulbaghia violacea) on BIC (bicuculline)-induced tonic convulsion in mice.

\begin{tabular}{|c|c|c|c|c|c|c|c|c|c|c|}
\hline \multicolumn{2}{|c|}{ Dose (mg/kg) } & \multirow[t]{2}{*}{ Phenobarbitone } & \multirow[t]{2}{*}{ Diazepam } & \multirow[t]{2}{*}{ Phenytoin } & \multirow[t]{2}{*}{ Muscimol } & \multirow[t]{2}{*}{ DMSO } & \multirow{2}{*}{$\begin{array}{l}\text { No convulsed/No } \\
\text { used }\end{array}$} & \multirow{2}{*}{$\begin{array}{l}\text { Percentage } \\
\text { protection } \\
(\%)\end{array}$} & \multicolumn{2}{|c|}{$\begin{array}{c}\text { Onset of tonic } \\
\text { convulsion (min) }\end{array}$} \\
\hline $\mathrm{PCN}$ & TV & & & & & & & & \multicolumn{2}{|c|}{ Mean \pm SEM } \\
\hline 30 & - & - & - & - & - & - & $8 / 8$ & & 2.38 & 0.42 \\
\hline 30 & 100 & - & - & - & - & - & $8 / 8$ & 0 & $5.63^{*}$ & 0.38 \\
\hline 30 & 200 & - & - & - & - & - & $8 / 8$ & 0 & $5.88^{*}$ & 0.30 \\
\hline 30 & 400 & - & - & - & - & - & $8 / 8$ & 0 & $10.28^{*}$ & 1.37 \\
\hline 30 & - & 12 & - & - & - & - & $1 / 8^{++}$ & 87.5 & $15.37^{*}$ & 0.89 \\
\hline 30 & - & - & 0.5 & - & - & - & $1 / 8^{++}$ & 87.5 & $19.25^{*}$ & 1.12 \\
\hline 30 & - & - & - & 30 & - & - & $8 / 8$ & 0 & 2.44 & 0.51 \\
\hline 30 & - & - & - & - & 2 & - & $1 / 8^{+}$ & 87.5 & $20.02^{*}$ & 1.27 \\
\hline 30 & - & - & - & - & - & $0.25 \mathrm{~mL}$ & $8 / 8$ & 0 & 2.34 & 0.60 \\
\hline
\end{tabular}

${ }^{\prime \prime} p<0.01,{ }^{* *} p<0.001$ compared to bicuculline $\left(30 \mathrm{mg} / \mathrm{kg}\right.$, i.p.) control, ANOVA $(\mathrm{n}=8) ;{ }^{+} p<0.005$ compared to bicuculline (30 $\mathrm{mg} / \mathrm{kg}$, i.p.) control, Chi-squared test $(\mathrm{n}=8)$. DMSO: Dimethylsulfoxide.

3.2.3 Effect of leaf methanol extract of TV (Tulbaghia violacea) on PCN (picrotoxin)-induced tonic convulsion

Picrotoxin (20 mg/kg, i.p.) elicited tonic convulsion in $100 \%$ of mice used for the experiment. Leaf methanol extract of Tulbaghia violacea (100, 200 and $400 \mathrm{mg} / \mathrm{kg}$, i.p.) significantly and dose dependently delayed the onset of the picrotoxin $(20 \mathrm{mg} / \mathrm{kg}$, i.p.)-elicited tonic convulsion but did not significantly alter the incidence of the convulsion. Phenobarbitone (12 $\mathrm{mg} / \mathrm{kg}$, i.p.), diazepam (0.5 $\mathrm{mg} / \mathrm{kg}$, i.p.) or muscimol (2 $\mathrm{mg} / \mathrm{kg}$, i.p.) significantly delayed the onset of picrotoxin $(20 \mathrm{mg} / \mathrm{kg}$, i.p.)-induced tonic convulsion and also significantly reduced the number of animals convulsing. Both diazepam $(0.5 \mathrm{mg} / \mathrm{kg}$, i.p.) and muscimol ( $2 \mathrm{mg} / \mathrm{kg}$, i.p.) protected $87.5 \%$ of the animals against picrotoxin $(20 \mathrm{mg} / \mathrm{kg}$, i.p.)-elicited tonic convulsion respectively. Phenobarbitone (12 $\mathrm{mg} / \mathrm{kg}$, i.p.) protected $75 \%$ of mice against the tonic convulsion. Phenytoin (30 mg/kg, i.p.) or DMSO (0.25 ml, i.p.) did not significantly affect the onset or incidence of picrotoxin $(20 \mathrm{mg} / \mathrm{kg}$, i.p.)-induced tonic convulsion (Table 3 ).

3.2.4 Effect of leaf methanol extract of TV (Tulbaghia violacea) on STN (strychnine)-induced tonic convulsion

Strychnine ( $2 \mathrm{mg} / \mathrm{kg}$, i.p.) produced tonic convulsion in all the eight mice used for the experiment. Leaf methanol extract of Tulbaghia violacea (200 and 400 $\mathrm{mg} / \mathrm{kg}$, i.p.) significantly delayed the onset of strychnine ( $2 \mathrm{mg} / \mathrm{kg}$, i.p.)-induced tonic convulsion but did not affect the number of mice convulsing. The dose of $100 \mathrm{mg} / \mathrm{kg}$ (i.p.) of leaf methanol extract of $T$. violacea did not significantly affect the onset or incidence of strychnine $(2 \mathrm{mg} / \mathrm{kg}$, i.p.)-induced tonic convulsion. Phenobarbitone (12 $\mathrm{mg} / \mathrm{kg}$, i.p.) significantly delayed the onset of strychnine $(2 \mathrm{mg} / \mathrm{kg}$, i.p.)-induced tonic convulsion and also significantly reduced the number of animals convulsing. The dose of $12 \mathrm{mg} / \mathrm{kg}$ (i.p.) of phenobarbitone protected $62.5 \%$ of mice against strychnine $(2 \mathrm{mg} / \mathrm{kg}$, i.p.)-induced tonic convulsion. Diazepam ( $0.5 \mathrm{mg} / \mathrm{kg}$, i.p.), phenytoin (30 $\mathrm{mg} / \mathrm{kg}$, i.p.) or DMSO (0.25 mL, i.p.) did not significantly delay the onset of strychnine $(2 \mathrm{mg} / \mathrm{kg}$, i.p.)-induced tonic convulsion and also did not significantly affect the number of mice convulsing (Table 4).

3.2.5 Effect of leaf methanol extract of TV (Tulbaghia violacea) on N-methyl-DL aspartic acid (NMDLA)-induced seizures

The dose of $400 \mathrm{mg} / \mathrm{kg}$ (i.p.) of $\mathrm{N}$-methyl-DL-aspartic acid (NMDLA) produced tonic convulsion in $100 \%$ of mice used. Leaf methanol extract of Tulbaghia violacea (100, 200 and 400 $\mathrm{mg} / \mathrm{kg}$, i.p.) significantly and dose dependently delayed the onset of NMDLA $(400 \mathrm{mg} / \mathrm{kg}$, i.p.)-induced tonic convulsion but did not significantly affect the incidence of the tonic convulsion. LY233053 
Table 3 Effect of leaf methanol extract of TV (Tulbaghia violacea) on PCN (picrotoxin)-induced tonic convulsion in mice.

\begin{tabular}{|c|c|c|c|c|c|c|c|c|c|c|}
\hline \multicolumn{2}{|c|}{ Dose $(\mathrm{mg} / \mathrm{kg})$} & \multirow[t]{2}{*}{ Phenobarbitone } & \multirow[t]{2}{*}{ Diazepam } & \multirow[t]{2}{*}{ Phenytoin } & \multirow[t]{2}{*}{ Muscimol } & \multirow[t]{2}{*}{ DMSO } & \multirow{2}{*}{$\begin{array}{l}\text { No convulsed/No } \\
\text { used }\end{array}$} & \multirow{2}{*}{$\begin{array}{l}\text { Percentage } \\
\text { protection } \\
(\%)\end{array}$} & \multicolumn{2}{|c|}{$\begin{array}{c}\text { Onset of tonic } \\
\text { convulsion (min) }\end{array}$} \\
\hline $\mathrm{PCN}$ & TV & & & & & & & & \multicolumn{2}{|c|}{ Mean \pm SEM } \\
\hline 20 & & - & - & - & - & - & $8 / 8$ & & 8.50 & 0.42 \\
\hline 20 & 100 & - & - & - & - & - & $8 / 8$ & 0 & $11.38^{*}$ & 1.07 \\
\hline 20 & 200 & - & - & - & - & - & $8 / 8$ & 0 & $13.00^{*}$ & 0.73 \\
\hline 20 & 400 & - & - & - & - & - & $8 / 8$ & 0 & $18.00^{*}$ & 0.91 \\
\hline 20 & - & 12 & - & - & - & - & $2 / 8^{++}$ & 75 & $21.33^{*}$ & 1.02 \\
\hline 20 & - & - & 0.5 & - & - & - & $1 / 8^{++}$ & 87.5 & $19.86^{*}$ & 0.95 \\
\hline 20 & - & - & - & 30 & - & - & $8 / 8$ & 0 & 8.64 & 0.82 \\
\hline 20 & - & - & - & - & 2 & - & $1 / 8^{+}$ & 87.5 & $22.75^{*}$ & 1.16 \\
\hline 20 & - & - & - & - & - & $0.25 \mathrm{~mL}$ & $8 / 8$ & 0 & 8.73 & 0.59 \\
\hline
\end{tabular}
picrotoxin $(20 \mathrm{mg} / \mathrm{kg}$,i.p. $)$ control, Chi-squared test $(\mathrm{n}=8)$. DMSO: Dimethylsulfoxide.

Table 4 Effect of leaf methanol extract of TV (Tulbaghia violacea) on STN (strychnine)-induced tonic convulsion in mice.

\begin{tabular}{|c|c|c|c|c|c|c|c|c|c|}
\hline \multicolumn{2}{|c|}{ Dose (mg/kg) } & \multirow[t]{2}{*}{ Phenobarbitone } & \multirow[t]{2}{*}{ Diazepam } & \multirow[t]{2}{*}{ Phenytoin } & \multirow[t]{2}{*}{ DMSO } & \multirow[t]{2}{*}{ No convulsed/No used } & \multirow{2}{*}{$\begin{array}{l}\text { Percentage } \\
\text { protection } \\
(\%)\end{array}$} & \multirow{2}{*}{\multicolumn{2}{|c|}{$\begin{array}{c}\begin{array}{c}\text { Onset of tonic } \\
\text { convulsion }(\mathrm{min})\end{array} \\
\text { Mean }+ \text { SEM }\end{array}$}} \\
\hline $\mathrm{PCN}$ & TV & & & & & & & & \\
\hline 2 & & - & - & - & - & $8 / 8$ & & 2.63 & 0.26 \\
\hline 2 & 100 & - & - & - & - & $8 / 8$ & 0 & 2.75 & 0.16 \\
\hline 2 & 200 & - & - & - & - & $8 / 8$ & 0 & $4.13^{*}$ & 0.23 \\
\hline 2 & 400 & - & - & - & - & $8 / 8$ & 0 & $3.88^{*}$ & 0.13 \\
\hline 2 & - & 12 & - & - & - & $3 / 8^{+}$ & 62.5 & $16.72^{* *}$ & 1.50 \\
\hline 2 & - & - & 0.5 & - & - & $8 / 8$ & 0 & 2.60 & 0.85 \\
\hline 2 & - & - & - & 30 & - & $8 / 8$ & 0 & 2.57 & 0.32 \\
\hline 2 & - & - & - & - & $0.25 \mathrm{~mL}$ & $8 / 8$ & 0 & 8.73 & 0.59 \\
\hline
\end{tabular}
control, Chi-squared test $(\mathrm{n}=8)$. DMSO: Dimethylsulfoxide.

(5 $\mathrm{mg} / \mathrm{kg}$, i.p.) significantly delayed the onset of NMDLA (400 mg/kg, i.p.)-induced tonic convulsion and significantly reduced the number of animals convulsing. The dose of $5 \mathrm{mg} / \mathrm{kg}$ (i.p.) of LY233053 protected $87.5 \%$ of mice against NMDLA $(400 \mathrm{mg} / \mathrm{kg}$, i.p.)-induced tonic convulsion. Phenobarbitone (12 $\mathrm{mg} / \mathrm{kg}$, i.p.), diazepam (0.5 mg/kg, i.p.), phenytoin (30 $\mathrm{mg} / \mathrm{kg}$, i.p.) and DMSO (0.25 mL, i.p.) did not significantly affect the onset of NMDLA $(400 \mathrm{mg} / \mathrm{kg}$, i.p.)-induced tonic convulsion or the incidence of the tonic convulsion (Table 5).

\subsection{Acute Toxicity}

Leaf methanol extract of Tulbaghia violacea $(100-4000 \mathrm{mg} / \mathrm{kg}$, p.o.) produced no signs of acute toxicity or deaths in mice after 5 days of observation.
The highest dose, $4,000 \mathrm{mg} / \mathrm{kg}$ (p.o.), tested is taken as the NOAEL (no-adverse-effect-level) since no signs of acute toxicity were observed at this dose level. The $\mathrm{LD}_{50}$ obtained for $T$. violacea following oral administration may probably be greater than 4000 $\mathrm{mg} / \mathrm{kg}$.

\subsection{HPLC Analysis}

The HPLC fingerprint of the leaf methanol extract of Tulbaghia violacea showed distinct peaks at the following retention times, 2.911, 3.269, 4.010, 7.597, and 15.122 min (Fig. 1).

\section{Discussion}

The study evaluated the anticonvulsant activity of the leaf methanol extract of Tulbaghia violacea with a 
Table 5 Effect of leaf methanol extract of TV (Tulbaghia violacea) on NMDLA (N-methyl-DL aspartic acid)-induced tonic convulsion in mice.

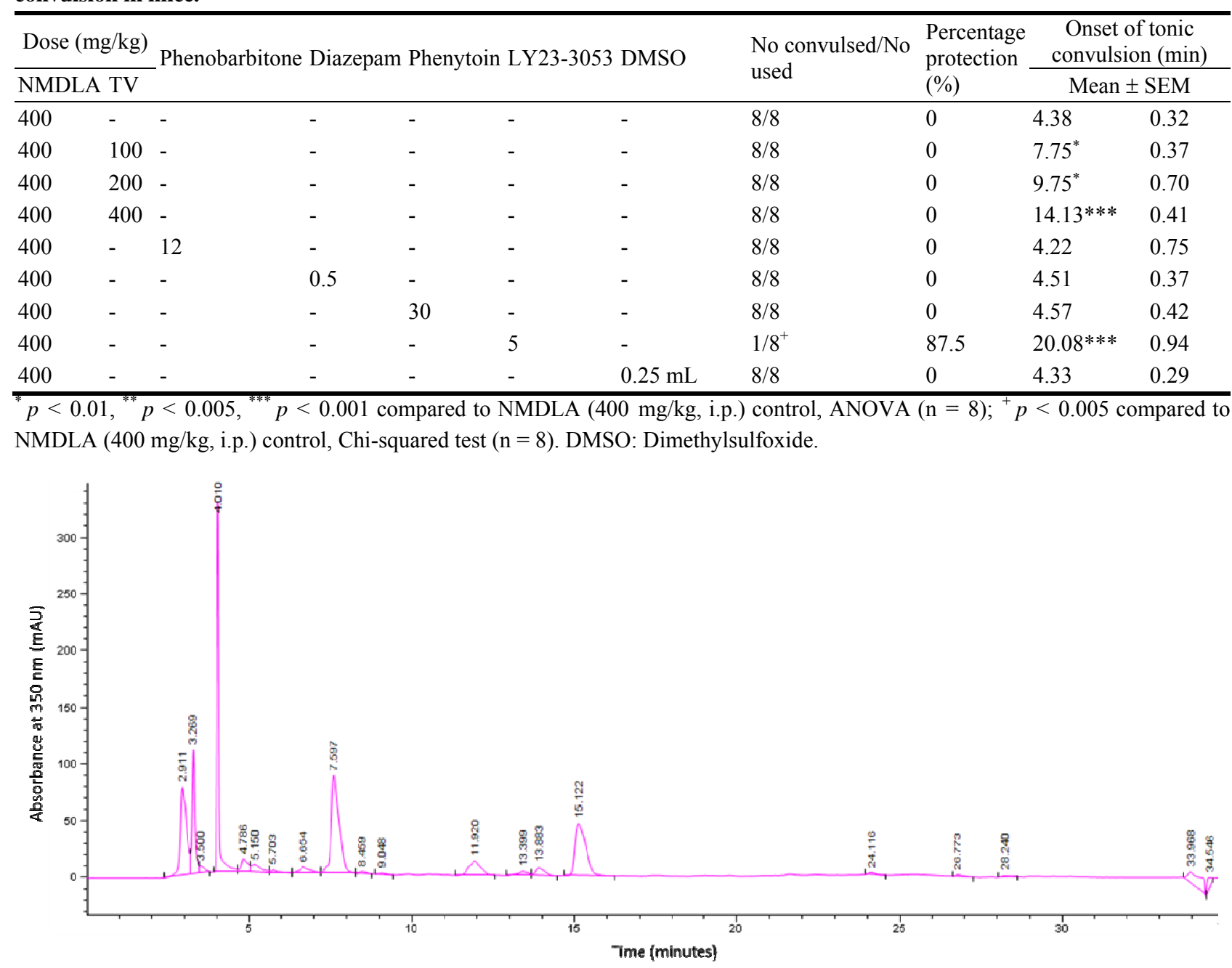

Fig. 1 HPLC fingerprint of methanol leaf extract of Tulbaghia violacea.

view to scientifically scrutinize the effectiveness of the plant species in the treatment of epilepsy as claimed by traditional medicine practitioners. The study also investigated possible mechanism(s) of the plant species' anticonvulsant activity by using convulsant agents known to affect certain neurotransmitters in the central nervous system implicated in epilepsy. The present study shows that pentylenetetrazole (PTZ, $100 \mathrm{mg} / \mathrm{kg}$, i.p.), bicuculline (30 mg/kg, i.p.), picrotoxin (12 mg/kg, i.p.), strychnine or NMDLA (400 $\mathrm{mg} / \mathrm{kg}$, i.p.) produced tonic convulsion in all the mice used. Leaf methanol extract of Tulbaghia violacea $(200-400 \mathrm{mg} / \mathrm{kg}$, i.p.) attenuated the tonic convulsions produced by PTZ or strychnine. The doses of $100-400 \mathrm{mg} / \mathrm{kg}$ (i.p.) attenuated the tonic convulsions produced by either bicuculline, picrotoxinor NMDLA. Phenobarbitone (12 $\mathrm{mg} / \mathrm{kg}$, i.p.) and diazepam $(0.5 \mathrm{mg} / \mathrm{kg}$, i.p.) attenuated the tonic convulsions produced by either PTZ, bicuculline or picrotoxin but did not affect NMDLA-induced tonic convulsion. Muscimol (2 $\mathrm{mg} / \mathrm{kg}$, i.p.) attenuated the tonic convulsions produced by PTZ, bicuculline or picrotoxin. Phenytoin (30 $\mathrm{mg} / \mathrm{kg}$, i.p.) did not affect the tonic convulsions produced by PTZ, bicuculline, picrotoxin, strychnine or NMDLA. LY23350 (5 mg/kg, i.p.) attenuated NMDLA-induced tonic convulsion. Phenobarbitone $(12 \mathrm{mg} / \mathrm{kg}$, i.p.) attenuated the tonic convulsions produced by strychnine. Olsen [30], Waller et al. [31] 
and Rang et al. [32], reported that an imbalance between GABA (gamma amino butyric acid), a major inhibitory neurotransmitter, and glutamic acid, an excitatory neurotransmitter in the brain underpins epilepsy. The inhibition of GABA mediated inhibition at $\mathrm{GABA}_{\mathrm{A}}$ receptors and the enhancement of glutamic acid neurotransmission at NMDA receptors in the brain may cause convulsion [30-32]. Pentylenetetrazole is thought to act by blocking $\mathrm{GABA}_{\mathrm{A}}$ receptors thus inhibiting GABA neurotransmitter [32, 33]. According to Waller et al. [31] and Rang et al. [32], phenobarbitone and diazepam, standard antiepileptic drugs, are known to act by enhancing GABA neurotransmission in the brain by respectively increasing the duration and frequency of the opening of $\mathrm{GABA}_{\mathrm{A}}$ receptor-linked chloride channels in the $\mathrm{GABA}_{\mathrm{A}}$ receptor-chloride ionophore complex to facilitate chloride ion conductance into the brain. It is not surprising therefore, that phenobarbitone and diazepam attenuated PTZ-induced tonic convulsion in the present study. Phenytoin, a standard antiepileptic drug, acts by blocking the entry of sodium ions into brain cells thus, inhibiting the generation of repetitive action potential [31, 32] and therefore, it did not affect PTZ-induced tonic convulsion in this study. According to Rang et al. [32] and Lança [34], muscimol, a selective and potent $\mathrm{GABA}_{\mathrm{A}}$ receptor agonist, acts by interacting with $\mathrm{GABA}_{\mathrm{A}}$ receptors in the brain to mimic the effects of GABA. Accordingly, muscimol significantly attenuated PTZ-induced tonic convulsion in mice as shown in our study. In this study, leaf methanol extract of Tulbaghia violacea was shown to attenuate PTZ-induced the tonic convulsion. It is therefore, possible to suggest that Tulbaghia violacea may be affecting GABA mechanism to produce its anticonvulsant activity. The combined therapy of sub-effective doses of Tulbaghia violacea and muscimol, significantly attenuated PTZ-induced tonic convulsion. This supports the suggestion that GABA mechanism may be involved in the anticonvulsant activity of Tulbaghia violacea. According to Rang et al.
[32] and Nicoll [35], bicuculline, a $\mathrm{GABA}_{\mathrm{A}}$ receptor antagonist, produces its convulsant activity by blocking $\mathrm{GABA}_{\mathrm{A}}$ receptors and this inhibits GABA neurotransmission in the brain. In this study, bicuculline produced tonic convulsion which was attenuated by phenobarbitone and diazepam, both of which are known to enhance GABA neurotransmission in the brain [32]. Furthermore, muscimol, a specific $\mathrm{GABA}_{\mathrm{A}}$ receptor agonist, known to mimic the effect of $\mathrm{GABA}$ at $\mathrm{GABA}_{\mathrm{A}}$ receptors in the brain, was shown to attenuate bicuculline-induced tonic convulsion. Leaf methanol extract of Tulbaghia violacea also attenuated bicuculline-induced tonic convulsion. Phenytoin, known to exert its antiepileptic effects by blocking sodium ion entry into the brain, did not attenuate bicuculline-induced tonic convulsion. These findings further support the suggestion that GABA mechanism may be involved in the anticonvulsant activity of Tulbaghia violacea. Picrotoxin is known to produce convulsion by blocking $\mathrm{GABA}_{\mathrm{A}}$ receptor-linked chloride ion channel to prevent the entry of chloride ions into the brain and this inhibits it GABA-mediated inhibition [32]. The present study shows that picrotoxin-induced tonic convulsion in mice was attenuated by phenobarbitone and diazepam, both of which are known to enhance GABA neurotransmission in the brain. Muscimol, a specific $\mathrm{GABA}_{\mathrm{A}}$ receptor agonist, known to mimic the effect of GABA at $\mathrm{GABA}_{\mathrm{A}}$ receptors, also attenuated picrotoxin-induced tonic convulsion. Leaf methanol extract of Tulbaghia violacea also attenuated picrotoxin-induced tonic convulsion. On the other hand, phenytoin, known to produce its anticonvulsant effect by blocking sodium ion entry into the brain, did not affect picrotoxin-induced tonic convulsion. These findings further show that GABA mechanism may be involved in the anticonvulsant activity of Tulbaghia violacea. According to Rang et al. [32], strychnine produces convulsion by blocking receptors for glycine in the brain. In this study, phenobarbitone and leaf methanol extract of Tulbaghia violacea attenuated 
strychnine-induced tonic convulsion. These findings suggest that glycine mechanism may also be involved in the anticonvulsant activity of Tulbaghia violacea. Rang et al. [32] have reported that phenobarbitone may produce its anticonvulsant activity by different mechanisms. In view of the antagonistic effect of phenobarbitone on stychnine-induced tonic convulsion in this study, it is possible that phenobarbitone may also be producing its anticonvulsant activity by enhancing glycinergic neurotransmission in the brain. Benzodiazepines have been shown not to alter strychnine-induced convulsion in experimental animals [32]. However, moderate to high doses of IV phenobarbitone, IV diazepam and IV phenytoin have been used to prevent strychnine convulsion in strychnine poisoning in humans [36, 37]. According to Rang et al. [32], Chapman and Meldrum [38], and Besancon et al. [39], NMDLA (N-Methyl-DL-aspartic) acid produces its anticonvulsant effects by specifically stimulating NMDA receptors to mimic the action of glutamate, the excitatory neurotransmitter in the brain. The present study shows that phenobarbitone and diazepam, both of which are known to enhance GABA neurotransmission in the brain, did not affect NMDLA-induced tonic convulsion in mice. LY233053, in this study, attenuated NMDLA-induced tonic convulsion. According to Madden et al. [40] and Borowicz et al. [41], LY233053 is a competitive NMDA receptor antagonist, which acts by blocking the effect of glutamic acid at NMDA receptors. Leaf methanol extract of Tulbaghia violacea attenuated NMDLA-induced tonic convulsion. Phenytoin known to exert its anticonvulsant effect by blocking sodium ion entry into the brain did not alter NMDLA-induced tonic convulsion. These findings suggest the possible involvement of glutamic acid mechanism(s) in the anticonvulsant activity of Tulbaghia violacea. In this study, the phytochemical qualitative analysis of the dried powdered leaf extract of Tulbaghia violacea revealed the presence of alkaloids, saponins, reducing sugars, flavonoids cardiac glycosides, triterpene steroids, quinones and tannins. Alkaloids, flavonoids, saponins and triterpene steroids have been shown in different studies to possess anticonvulsant activities [42-48]. It is possible therefore, that these secondary metabolites may be contributing to the anticonvulsant activity of Tulbaghia violacea. The result obtained from the acute toxicity study carried out showed that following oral administration of the leaf methanol extract to mice, the $\mathrm{LD}_{50}$ may be greater than 4000 $\mathrm{mg} / \mathrm{kg}$. This suggests that Tulbaghia violacea may be safe in and non-toxic to the animals. The HPLC finger print obtained for Tulbaghia violacea revealed the presence of characteristics peaks at the wave light of $350 \mathrm{~nm}$ which may be used to identify the exact species of Tulbaghia violacea.

\section{Conclusions}

The results obtained in this study indicate that the leaf methanol extract of Tulbaghia violacea has an anticonvulsant activity which may involve GABA, glutamic acid and glycine mechanisms. Secondary metabolites such as saponins, triterpene steroids, alkaloids and flavonoids found in the leaves of the plant species may also in part be contributing to the anticonvulsant activity. The relatively high $\mathrm{LD}_{50}$ value obtained for the plant species following oral administration shows that it is safe in mice. These findings justify the use of Tulbaghia violacea by traditional practitioners in the management and treatment of epilepsy. However, further studies are needed to further elucidate the mechanism(s) of the anticonvulsant activity of Tulbaghia violacea. Further toxicological studies are also needed to establish the safety profile of the plant species.

\section{Acknowledgments}

The National Research Foundation, South Africa (Grant number: 67983) and the Libyan Embassy, South Africa supported the study financially. The authors wish to thank the management of Kirstenbosch National Botanical Gardens, Cape Town, South Africa, 
for donating the plant material and the technical staff of the Department of Medical Biosciences and the Discipline of Pharmacology and Clinical Pharmacy, University of the Western Cape, South Africa, for their valuable technical support.

\section{References}

[1] Chang, B. S., and Lowenstein, D. H. 2003. "Epilepsy." New England Journal of Medicine 349: 1257-66.

[2] De Boer, H. M., Mula, M., and Sander, J. W. 2008. "The Global Burden and Stigma of Epilepsy." Epilepsy and Behavior 12 (4): 540-46.

[3] Van Mierlo, P., Papadopoulou, M., Carrette, E., Boon, P., Vandenberghe, S., Vonck, K., and Marinazzo, D. 2014. "Functional Brain Connectivity from EEG in Epilepsy: Seizure Prediction and Epileptogenic Focus Localization." Progress in Neurobiology 121: 19-35.

[4] Perucca, E., Arroyo, S., Baldy-Moulinier, M., Dulac, O., Eskasan, E., Halasz, P., and Johannessen, S. 2001. ILAE Commission Report: Evaluations and Awards at the 4th European Congress of Epileptology. Florence, 7-12.

[5] Preux, P. M., and Druet-Cabanac, M. 2005. "Epidemiology and Aetiology of Epilepsy in Sub-Saharan Africa." The Lancet Neurology 4 (1): 21-31.

[6] Hung, A. T. F. 2009. "Psycho-Social Impact of Epilepsy and Issues of Stigma." Medical Bulletin 14 (5): 15-7.

[7] Boison, D. 2010. "Inhibitory RNA in Epilepsy: Research Tools and Therapeutic Perspectives." Epilepsia 51 (9): 1659-68.

[8] Kwan, P., and Brodie, M. J. 2000. "Early Identification of Refractory Epilepsy." New England Journal of Medicine 342 (5): 314-19.

[9] Shibre, T., Alem, A., Tekle-Haimanot, R., and Medhin, G. 2006. "Perception of Stigma in People with Epilepsy and Their Relatives in Butajira, Ethiopia." Ethiopian Journal of Health Development 20 (3): 170-76.

[10] Schmidt, D. 2009. "Drug Treatment of Epilepsy: Options and Limitations." Epilepsy and Behavior 15 (1): 56-65.

[11] Kayne, S. B. 2009. Introduction to Traditional Medicine. Complementary and Alternative Medicine (2nd ed.). London: Pharmaceutical Press.

[12] Van Wyk, B. E., Oudtshoorn, B. V., and Gericke, N. 1997. Medicinal Plants of South Africa. Pretoria: Briza.

[13] Amabeoku, G. J., Leng, M. J., and Syce, J. A. 1998. "Antimicrobial and Anticonvulsant Activities of Viscumcapense." Journal of Ethnopharmacology 61 (3): 237-41.

[14] Jäger, A. K., Mohoto, S. P., van Heerden, F. R., and Viljoen, A. M. 2005. "Activity of a Traditional South African Epilepsy Remedy in the GABA-Benzodiazepine
Receptor Assay." Journal of Ethnopharmacology 96 (3): 603-06.

[15] Light, M. E., Sparg, S. G., Stafford, G. I., and Van Staden, J. 2005. "Riding The Wave: South Africa's Contribution to Ethno pharmacological Research over the Last 25 Years." Journal of Ethnopharmacology 100 (1): 127-30.

[16] Govender, N., Trollope, W. S., and Van Wilgen, B. W. 2006. "The Effect of Fire Season, Fire Frequency, Rainfall and Management on Fire Intensity in Savannah Vegetation in South Africa." Journal of Applied Ecology 43 (4): 748-58.

[17] Keikelame, M. J., and Swartz, L. 2007. "Parents' Understanding of the Causes and Management of Their Children's Epilepsy in Khayelitsha, Cape Town." South African Journal of Psychology 37 (2): 307-15.

[18] Raskin, I. 2003. Plants and Pharmaceuticals in the 21st Century in Plant Biotechnology 2002 and Beyond. Netherlands: Springer.

[19] Ekstein, D., and Schachter, S. C. 2010. "Natural Products in Epilepsy-The Present Situation and Perspectives for the Future."Pharmaceuticals 3 (5): 1426-45.

[20] Advani, U., Ansari, A., and Menghani, E. 2011. "Anticonvulsant Potentials of Sesamum Indicum and Allium Sativumoil Alone and in Combination in Animal Model." International Journal of Pharmacy and Pharmaceutical Science 3 (4): 154-58.

[21] Amabeoku, G. J., and Kinyua, C. G. 2010. "Evaluation of the Anticonvulsant Activity of Zanthoxylumcapense (Thunb.) Harv. (Rutaceae) in Mice." International Journal of Pharmacology 6 (6): 844-53.

[22] Harbone, J. B. 1984. Phytochemical Methods: A Guide to Modern Techniques of Plant Analysis (2nd ed.). London: Chapman and Hall Ltd.

[23] Ikhiri, K., Boubima, D., and Kouloda, D. D. 1992. "Chemical Screening of Medicinal Plants Used in the Traditional Pharmacopoeia of Niger." International Journal of Pharmacognosy 30: 251-62.

[24] Vellucci, S. V., and Webster, R. A. 1984. "Antagonism of Caffeine-Induced Seizures in Mice by Ro 15-1788." European Journal of Pharmacology 97 (3): 289-93.

[25] Amabeoku, G. J., Mbamalu, O. N., Davids, T., Fakude, S., Gqwaka, A., Mbai, F. N., and Shaik, A. 2014. "Evaluation of the Anticonvulsant Activity of the Leaf Methanol Extract of Crassulaarborescens (Mill.) Willd. (Crassulaceae) in Mice." Journal of Pharmacy and Pharmacology 2: 393-403.

[26] El Hilaly, J., Israili, Z. H., and Lyoussi, B. 2004. "Acute and Chronic Toxicological Studies of Ajugaiva in Experimental Animals." Journal of Ethnopharmacology 91 (1): 43-50.

[27] Lorke, D. 1983. "A New Approach to Practical Acute Toxicity Testing." Archives of Toxicology 54 (4): 275-87. 
[28] Ojewole, J. A. 2006. “Antinociceptive, Anti-inflammatory and Anti-diabetic Properties of Hypoxishemerocallidea Fisch. \& CA Mey. (Hypoxidaceae) Corm ['African Potato'] Aqueous Extract in Mice and Rats." Journal of Ethnopharmacology 103 (1): 126-34.

[29] Bienvenu, E., Amabeoku, G. J., Eagles, P. K., Scott, G., and Springfield, E. P. 2002. "Anticonvulsant Activity of Aqueous Extract of Leonotisleonurus." Phytomedicine 9 (3): 217-23.

[30] Olsen, R. W. 1981. "GABA-benzodiazepine-barbiturate Receptor Interactions." Journal of Neurochemistry 37: $1-13$.

[31] Waller, D. G., Renwick, A. G., and Hillier, K. 2005. Medicinal Pharmacology and Therapeutics (2nd ed.) Edinburgh: Elsevier Saunders.

[32] Rang, H. P., Dale, M. M., Ritter, J. M., Flower, R. J., and Henderson, G. 2016. Rang and Dale's Pharmacology (8th ed.). Edinburgh: Elsevier Churchill Livingstone.

[33] De Sarro, A., Cecchetti, V., Fravolini, V., Naccari, F., Tabarrini, O., \& De Sarro, G. 1999. "Effects of Novel 6-Desfluoroquinolones and Classic Quinolones on Pentylenetetrazole-Induced Seizures in Mice." Antimicrobial Agents and Chemotherapy 43 (7): 1729-36.

[34] Lança, A. J. 1998. "Functional Organization of the Central Nervous System.” In Principles of Medical Pharmacology (6th ed.), edited by Kalant, H., and Roschlau, W. H. E. Toronto: University of Toronto Press.

[35] Nicoll, R. A. 2001. "Introduction to the Pharmacology of Central Nervous System Drugs.” In Basic and Clinical Pharmacology, edited by Katzung, B. G. New York: Appleton and Lange.

[36] Lambert, J. R., Byrick, R. J., and Hammeke, M. D. 1981. "Management of Acute Strychnine Poisoning." Canadian Medical Association Journal 124 (10): 1268-69.

[37] Boyd, R. E., Brennan, P. T., Deng, J. F., Rochester, D. F., and Spyker, D. A. 1983. "Strychnine Poisoning: Recovery from Profound Lactic Acidosis, Hyperthermia, and Rhabdomyolysis." The American Journal of Medicine 74 (3): 507-12.

[38] Chapman, A. G., \& Meldrum, B. S. 1993. "Excitatory Amino Acid Antagonists and Epilepsy." Biochemical Society Transactions 21 (1): 106-10.

[39] Besancon, E., Guo, S., Lok, J., Tymianski, M., and Lo, E. H. 2008. "Beyond NMDA and AMPA Glutamate
Receptors: Emerging Mechanisms for Ionic Imbalance and Cell Death in Stroke." Trends in Pharmacological Sciences 29 (5): 268-75.

[40] Madden, K. P., Clark, W. M., Kochhar, A., and Zivin, J. A. 1992. "Efficacy of LY233053, A Competitive Glutamate Antagonist, in Experimental Central Nervous System Ischemia.” Journal of Neurosurgery 76 (1): 106-10.

[41] Borowicz, K. K., Gasior, M., Kleinrok, Z., and Czuczwar, S. J. 1996. "Competitive NMDA-Receptor Antagonists, LY 235959 and LY 233053, Enhance the Protective Efficacy of Various Antiepileptic Drugs against Maximal Electroshock-Induced Seizures in Mice.” Epilepsia 37 (7): 618-24.

[42] Abu Safieh, K. A., Al Eisawi, D. M., Abu Zarga, M. H., and Sabri, S. S. 1986. "Chemical Constituents of the Flora of Jordan II. Alkaloids of Leonticleonpatalum." Journal of Natural Products 49: 726-27.

[43] Chauhan, A. K., Dobhal, M. P., and Joshi, B. C. 1988. "A Review of Medicinal Plants Showing Anticonvulsant Activity."Journal of Ethnopharmacology 22 (1): 11-23.

[44] Mimaki, Y., Toshimizu, N., Yamada, K., and Sashida, Y. 1997. "Anti-convulsion Effects of Choto-San and Chotoko (Uncariaeuncis Cam Ramlus) in Mice, and Identification of the Active Principles." Journal of the Pharmaceutical Society of Japan 117 (12): 1011-21.

[45] Van Heerden, F. R., Viljoen, A. M., Mohoto, S. P., and Jäger, A. K. 2002. "A Phytochemical Investigation of Craterocapsatarsodes, a Plant Used for the Treatment of Epilepsy by the Northern Sotho People of South Africa." South African Journal of Botany 68 (1): 77-9.

[46] Muazu, J., and Kaita, M. H. 2008. "A Review of Traditional Plants Used in the Treatment of Epilepsy amongst The Hausa/Fulani Tribes of Northern Nigeria." African Journal of Traditional, Complementary and Alternative Medicines 5 (4): 387-90.

[47] Ibrahim, G., Abdulmumin, S., Musa, K. Y., and Yaro, A. H. 2008. "Anticonvulsant Activities of Crude Flavonoid Fraction of the Stem Bark of Ficussycomorus (Moraceae)." Journal of Pharmacology and Toxicology 3 (5): 351-56.

[48] Singh, D., Singh, B., and Goel, R. K. 2012. "Role of Saponins for the Anticonvulsant Effect of Adventitious Roots of Ficusreligiosa." Pharmaceutical Biology 50 (7), 816-22. 